Pakistan Journal of Humanities and Social Sciences

April - June 2019, Volume 7, No. 2, Pages 233 - 244

\title{
The Role of Physiological Contract Breach on Employee Reactions: Moderating Role of Organizational Trust
}

\author{
Sumaira Rehman ${ }^{1}$, Shahzad Ali ${ }^{2}$, Muhammad Sajjad Hussain ${ }^{3}$, Aamir Zamir Kamboh ${ }^{4}$ \\ ${ }^{1,2,3}$ Deparment of Management Sciences, The Superior College, Lahore Pakistan \\ ${ }^{4} \mathrm{Ph} . \mathrm{D}$. Candidate, School of Economics, Finance and Banking, Universiti Utara Malaysia \\ Email: sajjadgift@gmail.com
}

\begin{abstract}
Psychological contract Breach (PCB) play a crucial role to shape employee reactions (ERs) Therefore; this study investigated the possessions of Psychological contract Breach on employee's reactions (organizational behavior regarding citizenship, job satisfaction) under the moderation of organizational trust. Data were collected from 340 employees of the Health sector by using the technique of simple random sampling. Confirmatory factor analysis (CFA) technique has been used to check the validity of the data while structure equation modeling (SEM) technique has been used for test the relationship between variables. Our findings revealed that psychological contract breach had negative and significant relationships with employees' reactions (organizational citizenship behavior, job satisfaction). Further, organizational trust is also significantly moderated on the relationship between PCB and employees' reactions (organizational behavior regarding citizenship, job satisfaction).
\end{abstract}

Keywords: Psychological contract breach, Employee reaction, Organizational citizenship behaviors, Job performance, Organizational trust

\section{Introduction}

Human resource shortage situation has been existing in the healthcare sector of the world. World health gathering calls it "crises in physical condition. In the same way, the healthcare sector of Pakistan is confronting the like difficulty. In 1994, the management of Pakistan introduced lady health workers program (LHWP) to raise it. LHWs were hired to give services of health care to residents of the state and a smaller amount of urbanized area. These LHWs worked with sincerity and efficient. An important, the rural women in progress to follow healthcare services without uncertainty. These LHWs contain different problems regarding pay and endorsement, not reward of operating cost, deficiency of profit, life lack of confidence and obvious use (CLOSSER, 2015; Wazir, Shaikh, \& Ahmed, 2013). These troubles caused 
depressing responses, and these snags involve being permanent. In addition, similar scholars had contributed to observe ERs in specific contexts. In the same way, researchers had explored ERs, but incomplete research concentration had been known to examine the ERs of the LHWs. Most of the researchers from the ground of healthcare had explained the LHWs ${ }^{\text {ee }}$ troubles but before research had not examined the factor which complete ERs of the LHWs (Wazir et al., 2013).

ERs include a different mechanism, i.e., organizational citizenship behaviors (OCB), Job satisfaction. In adding, earlier studies had recognized many histories such as PCB, human resource administration practices(Bamford, Wong, \& Laschinger, 2013; Chambel, 2014). In the same way, ERs are reckon significant regarding diverse projects success of the organization. The institutional trust also has significance to increase governmental achievement. It has as well got an essential place to present just surroundings and to complete workers expectations at the workplace. Moreover, Agarwal, (2014) and Katou, (2013) used OT as a mediator in their study in a different context. Further, Aryee, Budhwar, and Chen (2002) had also explored OT as a mediator in their study on Pakistan. In addition, previous studies ignored the OT as moderator, particularly between the healthcare employees of Pakistan. For that reason, the current study addresses this space on the foundation of recommendations (Ghosh, Rai, \& Sinha, 2014; Kraft, 2008). So, the current study investigated the effects of PCB on ERs by using OT as moderator among the LHWs in Pakistan.

\section{Literature Review}

Employee Reactions are measured important factors which help to improve organizational achievement and efficiency. Employee Reactions exemplify different behaviors and attitudes of workers such as organizational citizenship behaviors and job satisfaction.

\section{A. Physiological contract}

Most of the previous researchers required to describe the psychological contract; the majority of these definitions have rebounded related themes that contain ideas, expectations, obligations, and reciprocity. This study used the definition such as psychological contract refers to the belief of employee in a joint responsibility between the organization and employee (Robinson, Kraatz, \& Rousseau, 1994). Most of the Researchers argued that the nature of the psychological contract is subjective and it depends on the viewpoints of employees regarding what responsibilities must be fulfilled by the organization (Robinson et al., 1994).

\section{B. Physiological contract Breach}


Pakistan Journal of Humanities and Social Sciences, 7(2), 2019

A PCB is referred to as the obligation of employees that their organization was unsuccessful in completing the obligations connected with past shared promises (Gakovic \& Tetrick, 2003). The achievement which is inconsistent with the faith of employees that create a mutual obligation that has the potential to build awareness in the eyes of employees regarding the contract breach (Robinson et al., 1994).

\section{Organization Trust}

Some of the previous studies describe that etymologically is the word trust that implies commitment and loyalty. Conversely, word trust roots probably were attached to the communities where most of the people want and began to live together, but the basis for any type of relations such as social relations is the trust. (Möllering, Bachmann, \& Hee Lee, 2004). In addition, trust is like a psychological condition that receives the goal of others without questioning. (Huff \& Kelley, 2003) Moreover, Organizational trust imitates the explicit keenness of employees in working (Tan \& Lim, 2009).

\section{Employee Reaction}

ERs are measured essential factors which support to improve organizational efficiency and success. ERs represent different attitudes and behaviors of workers such as promise, inspiration, appointment and behaviors of citizenship (Ahmad-Mughal, Nisar, Othman, \& Kamil, 2017; Asif, Nisar, Faisal, \& Khalid, 2017; Butt, Nisar, Nadeem, \& Baig, 2017; Gill, Nisar, Azeem, \& Nadeem, 2017; Katou, 2013; Nisar, Marwa, Ahmad, \& Ahmad, 2014; Saleem, Nisar, \& Imran, 2017).

\section{E. Job Performance}

Job performance refers to the effectiveness and efficiency of behaviors of human beings that help to achieve the organizational goals. In this learning, there are two dimensions of job performance such as contextual performance and task performance (Borman \& Motowidlo, 1993).

\section{F. Organization Citizenship Behavior (OCB)}

OCB refers to displaying helping, voluntary and extra-role behavior to the employees and support to the institution in different conscience and fields (Newton, Blanton, \& Will, 2008). The concept of OCB is that type in which employees go away from the expectations in accordance to fulfill the goals of the institution and show their behavior as self-sacrificing (Chiaburu \& Lim, 2008)".

\section{G. Psychological Contract Breach and Employee Reaction}


The current study inspected the impacts of PCB on job satisfaction and job outcomes, a purpose behind it to stay with associations such as perceived managerial support, and OCB. Additionally, this study also investigated whether the impact of PCB on these outcomes varied on the basis of various types of psychological contract. Data are collected from eighty-nine full and part-time workers. The results of the study indicated that breach of psychological contract of one employee had a vital impact on his job satisfaction and the purpose behind it to remain, and POS. In addition, there was a vital communication between PCB and the types of psychological contract in a way that when an employee experienced to breach his psychological agreement, the impact of PCB on PMS and OCB is different and depending on the type of psychological contract (S. Ahmad, Nisar, \& Naqvi, 2016; Ballou, 2013).

The current study investigated the relationship between PCB and job satisfaction. The prime objectives of current study were to examine the impact of PCB on job satisfaction. The scope of the study was the school of the private sector of Peshawar Pakistan. By using the technique of nonprobability convinces sampling of data collection, 380 questionnaires were distributed to a female and male teacher. Out of them only 276 questionnaires were filled and returned that was $72 \%$ of distributed questionnaires. On the basis of the literature, this study develops the hypothesis that there is a significant relationship between PCB and turnover purpose. However, the result of the study rejected the hypothesis and concluded that there is no significant relationship between PCB and turnover objective and also finds that PCB has significant impact on job Satisfaction. The study was quantitative by the natural and SPSS was used to composed and analyzed the data (A. Ahmad \& Khan, 2015).

\section{H. Organization Trust and Psychological Contract Breach}

The study by Erkutlu and Chafra (2013) conducted on ten universities of Turkey and date were collected from 848 teachers by using the technique of simple random sampling. They used moderated hierarchical regression to investigate the moderating impact of employees' trust between the relationship of managerial deviance association and sound management. (Erkutlu \& Chafra, 2013).

The purpose of the study is to examine whether genuine management is associated with organizational deviance or not and also investigate the moderating effects of PCB and workers' trust between these relationships. This study is a reply to the call for additional research on interpersonal and managerial factors that may hand out as moderators of abnormal behaviors (Yang et al., 2011). In addition, interpersonal and situational factors are middle to managerial deviance (Holtz \& Harold, 2013). Moreover, it is significant to observe the direct and 
moderating impacts of variables regarding social exchange in a study. Our information, this study is one of the first attempt to look at the moderating impacts of interpersonal variables on the place of work deviance in a particular study. (Erkutlu \& Chafra, 2013).

\section{Theoretical Model}

Figure 1: Liquidity Management, Systematic Risk, and Economic Indicators Interaction

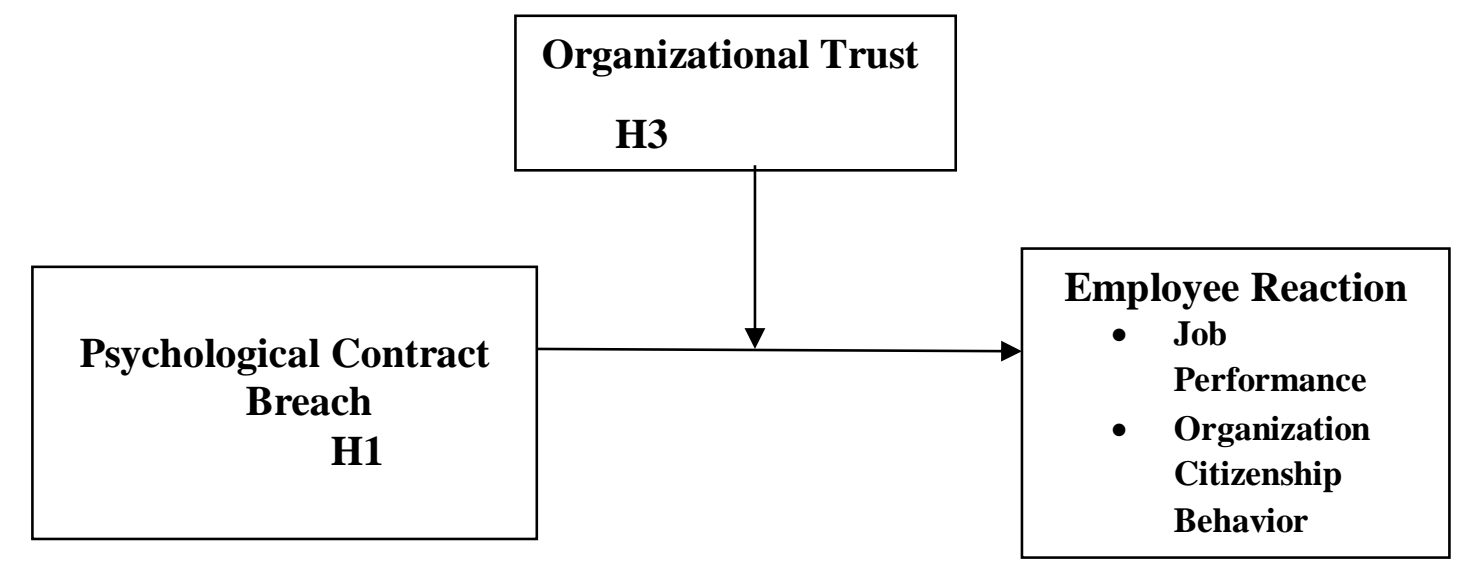

Source: The authors

\section{Methodology}

\section{A. Sample Size and Sampling Technique}

Sampling refers to a systematic process about selecting the portion of the population concerning inference the conclusion regarding the entire population (Singleton, Straits, \& Straits, 2005). This technique of sampling is quite suitable when the research is unable to collect data from entire population. In this case, researchers use the technique of sampling which allows comprehensive study results. Simple random sampling is one type of probability sampling in this sampling makes sure the equal right to participate. All the participants of the population have equal chances for selection (Baker, 2005).

The present study used a technique of simple random sampling to collect the data from respondents because by using this technique results get accurate, suitable trustworthy and comprehensive. In this study, the sample size is 300 .

\section{B. Measurements}

In this study, all measure and instrument adapted from the previous studies these studies suitable and trustworthy scales. This study used the five point Liker scale in term to measure the items of the variables. In this scale, five represents the "strongly agree", four represents the "agree", three represents the "neutral", two represents the "disagree" and one represents the "strongly disagree". 


\section{Psychological Contract Breach}

A scale by Cassar \& Buttigieg (2015) which consists of 4 items is used to measure the PCB. This scale is widely used in previous studies with high coefficient alpha value (Tsai, Chen, \& Liu, 2007). In addition, Wang (2011) reported the high value of coefficient alpha value $(\alpha=0.95)$ for task performance.

\section{Organizational Trust}

A scale that is used by Scott (1981) and also used by Ruder (2003) which consists of 4 items is used to measure the followers' Organizational trust. This scale is widely used in previous studies with high coefficient alpha value (Tsai et al., 2007). Wang (2011) reported the high value of coefficient alpha value $(\alpha=0.95)$ for task performance.

\section{E. Organizational Citizenship Behavior}

A scale that is used by Lee and Allen (2002) and also used by Saks (2006) which consists of 8 items is used to measure the followers' psychological Contract fulfillment. This scale is widely used in previous studies with high coefficient alpha value (Tsai et al., 2007).

\section{F. Liquidity Management}

A scale that is used by Cammann et al. (1983) and also used by Saks (2006) which consists of 3 items is used to measure the followers' psychological Contract fulfillment. This scale is widely used in previous studies with high coefficient alpha value (Tsai et al., 2007). In addition, Wang (2011) reported the high value of coefficient alpha value $(\alpha=0.95)$ for task performance.

\section{G. Procedure}

The current study collected data from the employees of the banks data through questionnaires these employees were working in different departments of universities and colleges. The participants came from a diversity of ranks of organizational hierarchy (low, mid, and upper-level). The data were collected from employees of different branches located in two cities; Lahore and Sargodha by using simple random sampling. About 500 questionnaires were distributed to the employees of the banks. Two ways for questionnaires sharing were adopted.

First, an online of questionnaires Second, hard copy of questionnaires were handed over HR with a request to share out among employees. About 320 questionnaires were returned (an actual response rate of 63.4 percent). For the duration of the data screening procedure, ten questionnaires (containing missing values) were eliminated, and ten questionnaires were disqualified because of outliers of values. Remain 300 questionnaires were used in the procedure of analysis (an effective response rate of 59.8 percent). 


\section{H. Data Analysis Techniques}

To check the perceptions of the respondent, this study used the demographic analysis, descriptive statistics, and correlation analysis and regression analysis is used to test the relationships between variables. The reliability and validity of the constructs is checked by using confirmatory factor analysis. While, this study used the technique of structure equation modeling (SEM) to check the hypotheses of the study.

\section{Data Analysis and Findings}

Table 1: Measure Model Assessment (Confirmatory Factor Analysis)

\begin{tabular}{|l|l|l|l|l|l|}
\hline Constructs & Items & Loadings & Alpha & CR & AVE \\
\hline Psychological Contract Breach & & & 0.819 & 0.881 & 0.654 \\
\hline & PCB1 & 0.734 & & & \\
\hline & PCB2 & 0.855 & & & \\
\hline & PCB3 & 0.847 & & & \\
\hline & PCB4 & 0.782 & & & \\
\hline Organizational Trust & & & 0.786 & 0.874 & 0.7 \\
\hline & OT1 & 0.743 & & & \\
\hline & OT2 & 0.882 & & & \\
\hline $\begin{array}{l}\text { Employee Reaction } \\
\text { Job Satisfaction }\end{array}$ & OT3 & 0.883 & & & \\
\hline & & & 0.071 & 0.786 & 0.554 \\
\hline & JS1 & 0.744 & & & \\
\hline OCB & JS2 & 0.832 & & & \\
\hline & JS3 & 0.644 & & & \\
\hline & OCB1 & 0.784 & 0.817 & 0.867 & 0.523 \\
\hline & OCB2 & 0.633 & & & \\
\hline & OCB3 & 0.792 & & & \\
\hline & OCB4 & 0.769 & & & \\
\hline & OCB5 & 0.692 & & & \\
\hline & OCB6 & 0.652 & & & \\
\hline
\end{tabular}

Table 1 highlights the composite reliability, factor loadings and average variance extract that ensure the convergent validity of the variables. It shows the loadings of all the indicators in the respective variables of the study. The convergent validity of the scale is said to be perfect if the items load highly (i.e., > 0.50) on their linked constructs (Hair, Ringle, \& Sarstedt, 2011). In this study, all the indicators were loaded on their exacting constructs from a lower bound of 0.590 to an upper bound of 0.852 .

Another measures to check the convergent validity are composite reliability and standard variance. If the value of AVE is greater than 0.50 and the value of composite reliability is greater than 0.80 then the convergent validity is perfect (Barclay, Higgins, \& Thompson, 
1995). The values of AVE of the study are above 0.50 and the values of composite reliability is greater than 0.8 that indicate the perfect the convergent validity of all constructs.

Table 2: Heterotrait-Monotrait Ratio

\begin{tabular}{|l|c|c|c|c|}
\hline & JS & OCB & OT & PCB \\
\hline JS & & & & \\
\hline OCB & 0.084 & & & \\
\hline OT & 0.794 & 0.85 & & \\
\hline PCB & 0.836 & 0.798 & 0.699 & \\
\hline
\end{tabular}

Table 2 of the study presented the HTMT ratio that is an efficient approach to check the discriminant validity of the variables. The value of HTMT ratio should be less than 0.90 to make sure the discriminant validity. The ratio of HTMT of this study is less than the 0.90 that is the proof of discriminant validity (Gold \& Arvind Malhotra, 2001).

Table 3: Structural Equation Modelling (SEM) Main Effects

\begin{tabular}{|l|l|l|l|l|l|l|l|}
\hline Hypothesis & Relationship & $\begin{array}{l}\text { Standardized } \\
\text { Beta }\end{array}$ & $\begin{array}{l}\text { Standard } \\
\text { Error }\end{array}$ & t-value & Decision & $\mathbf{R}^{\mathbf{2}}$ & $\mathbf{F}^{\mathbf{2}}$ \\
\hline H1a & PCB -> OCB & -0.529 & 0.078 & 6.805 & Supported & 0.456 & 0.04 \\
\hline H1b & PCB -> JS & -0.14 & 0.109 & 1.677 & Supported & 0.431 & 0.013 \\
\hline
\end{tabular}

Hypothesis 1a predicted the negative relationship between the PCB and organization citizenship Behavior intention of bank customers. Results concluded that the significant and negative relationship between PCB and OCB $(\beta=-0.529, \mathrm{t}=6.805)$ and support Hypothesis 1a. Furthermore, hypothesis $1 \mathrm{~b}$ predicted an effect of PCB on Job Satisfaction of bank employees. Results determined a significant and negative effect of PCB and job satisfaction ( $\beta$ $=-0.140, \mathrm{t}=1.677)$ and support to Hypothesis $1 \mathrm{~b}$.

Table 4: Moderating Role of Perceived Organizational Trust

\begin{tabular}{|l|l|l|l|l|l|}
\hline Hypothesis & Relationship & $\begin{array}{l}\text { Standardized } \\
\text { Beta }\end{array}$ & $\begin{array}{l}\text { Standard } \\
\text { Error }\end{array}$ & t-value & Decision \\
\hline H2a & PCB *OT->OCB & 0.09 & 0.089 & 0.437 & Supported \\
\hline H2b & PCB $*$ OT-> JS & 0.163 & 0.091 & 2.037 & Supported \\
\hline
\end{tabular}

The results shown in Table 4 , indicated that the interaction terms representing PCB*OT $(\beta=$ $0.163, t=2.037)$ are significant which means that organizational trust significantly moderates on the relationship of psychological contract Breach and employees' reactions.

\section{Conclusion and Discussions}

The result of the current study revealed that PCB is doing a very significant and positive impact in determining enhanced ERs among the Heath workers. Furthermore, the moderating 
impact of OT between the relations of PCB and ERs. This impact showed that in existence of health workers small rank of belief on organizations caused depressing actions still when the organization is given that reasonable surroundings and fulfilling their indirect promises.

These outcomes were matching with earlier studies (Chambel, 2014; Ghosh et al., 2014), (Chambel, 2014), (Kraft, 2008), (Elamin \& Tlaiss, 2015), (Bal, de Lange, Ybema, Jansen, \& van der Velde, 2011), (Loi, Hang-Yue, \& Foley, 2006). In addition, when workers observe that association is very soon and trustworthy in its business among them, people lean to show improved ERs. Moreover, the fair feeling inside the association encouraged workers to positive character reactions which in rotate supplement managerial success and efficiency (Gupta \& Kumar, 2012), (Elamin \& Tlaiss, 2015), (Ahmad et al., 2016) and (Biswas, Varma, $\&$ Ramaswami, 2013). In the same way, workers feel pleasure and show improved reactions when organization give pleasant interpersonal surroundings, show be concerned for human resources, complete their indirect promises. Moreover, the PCs implementation have a significant and positive effect on workers' reactions. (Kraft, 2008) (Moore, 2014) and (S. Ahmad et al., 2016). If association fulfill the PCs, the workers recognize that association principles and they are going to help to achieve the managerial Bunch mark by showing improved reactions. In the same way, my research had as well completed these results in the situation of the health sector in Pakistan. The outcome depicted that the health sector reacted absolutely at what time they observe that the organization provided just surroundings and complete their indirect responsibilities. The result showed that in the existence of OT these interactions were improved into the contrary side. The result was a little dissimilar from theoretical perspectives but similar to past research (Kraft, 2008). For example, Jiang examines the correlation of PCB and ERs in the existence of OT as a moderator between the universities teacher in different countries, i.e. Australia, Korea and China. The outcome of his study exposed that OT in a hostile way moderate this connection that means OT changes the directions of PCB effect on ERs (Jiang, 2015).

The current study has several limitations. This study was collected data at one point due to barriers and social norms. The respondents are interconnected with each other. The data were collected only from the health sector from Gujranwala and Lahore of the provinces of Punjab, Pakistan. Accordingly, the results might not be comprehensive to the other sector workers such as workers of service sector. In addition, this study suggested that to conduct a longitudinal study in future studies. Moreover, this study examined the impact of PCB on ERs. 
The current research examined the two mechanisms of ERs: Job Performance and OCB. Upcoming research should take in other apparatus, i.e., job satisfaction and turnover intentions.

\section{References}

Ahmad-Mughal, S., Nisar, Q. A., Othman, N., \& Kamil, B. A. M. (2017). Do Emotional Intelligence \& Organizational Politics influence the Employee Work Behaviors and attitudes? Mediating Role of Political Skill. Jurnal Pengurusan(51).

Ahmad, A., \& Khan, S. (2015). Psychological Contract Breaches and its Impact on Employee Turn over Intention and Job Satisfaction. European Journal of Business and Management, 7(10), 31-39.

Ahmad, S., Nisar, Q. A., \& Naqvi, S. M. (2016). Effect of psychological contract fulfillment and organizational justice on employee reactions under moderation by organizational trust: A study on the lady health workers in Pakistan. Science International, 28(1).

Asif, M., Nisar, Q. A., Faisal, H. M., \& Khalid, H. (2017). Does Corporate Social Responsibility influence the Organizational Citizenship Behavior and Organizational Commitment? Mediating Role of Organizational Trust \& Organizational Justice. Mediating Role of Organizational Trust \& Organizational Justice.

Baker, P. H. (2005). Managing student behavior: How ready are teachers to meet the challenge? American secondary education, 51-64.

Bal, P. M., de Lange, A. H., Ybema, J. F., Jansen, P. G., \& van der Velde, M. E. (2011). Age and trust as moderators in the relation between procedural justice and turnover: A largescale longitudinal study. Applied Psychology, 60(1), 66-86.

Ballou, N. S. (2013). The effects of psychological contract breach on job outcomes: San Jose State University.

Bamford, M., Wong, C. A., \& Laschinger, H. (2013). The influence of authentic leadership and areas of worklife on work engagement of registered nurses. Journal of nursing management, 21(3), 529-540.

Barclay, D., Higgins, C., \& Thompson, R. (1995). The Partial Least Squares (pls) Approach to Casual Modeling: Personal Computer Adoption Ans Use as an Illustration.

Biswas, S., Varma, A., \& Ramaswami, A. (2013). Linking distributive and procedural justice to employee engagement through social exchange: a field study in India. The International Journal of Human Resource Management, 24(8), 1570-1587.

Borman, W. C., \& Motowidlo, S. (1993). Expanding the criterion domain to include elements of contextual performance. Personnel Selection in Organizations; San Francisco: Jossey-Bass, 71.

Butt, S. S., Nisar, Q. A., Nadeem, S., \& Baig, F. (2017). Longitudinal study to examine the influence of emotional intelligence on organizational citizenship behavior: Mediating role of political skills. WALIA Journal, 33(1), 54-63. 
Pakistan Journal of Humanities and Social Sciences, 7(2), 2019

Chambel, M. J. (2014). Does the fulfillment of supervisor psychological contract make a difference?: Attitudes of in-house and temporary agency workers. Leadership and Organization Development Journal, 35(1), 20-37.

Chiaburu, D. S., \& Lim, A. S. (2008). Manager trustworthiness or interactional justice? Predicting organizational citizenship behaviors. Journal of business ethics, 83(3), 453467.

CLOSSER, S. (2015). Pakistan's lady health worker labor movement and the moral economy of heroism. Annals of Anthropological Practice, 39(1), 16-28.

Elamin, A. M., \& Tlaiss, H. A. (2015). Exploring the relationship between organizational citizenship behavior and organizational justice in the Islamic Saudi Arabian context. Employee Relations, 37(1), 2-29.

Erkutlu, H., \& Chafra, J. (2013). Effects of trust and psychological contract violation on authentic leadership and organizational deviance. Management Research Review, 36(9), 828-848.

Gakovic, A., \& Tetrick, L. E. (2003). Psychological contract breach as a source of strain for employees. Journal of business and Psychology, 18(2), 235-246.

Ghosh, P., Rai, A., \& Sinha, A. (2014). Organizational justice and employee engagement: Exploring the linkage in public sector banks in India. Personnel Review, 43(4), 628652.

Gill, S. S., Nisar, Q. A., Azeem, M., \& Nadeem, S. (2017). Does leadership authenticity repays mediating role of psychological empowerment?

Gold, A. H., \& Arvind Malhotra, A. H. S. (2001). Knowledge management: An organizational capabilities perspective. Journal of management information systems, 18(1), 185-214.

Gupta, V., \& Kumar, S. (2012). Impact of performance appraisal justice on employee engagement: a study of Indian professionals. Employee Relations, 35(1), 61-78.

Hair, J. F., Ringle, C. M., \& Sarstedt, M. (2011). PLS-SEM: Indeed a silver bullet. Journal of Marketing theory and Practice, 19(2), 139-152.

Holtz, B. C., \& Harold, C. M. (2013). Interpersonal justice and deviance: The moderating effects of interpersonal justice values and justice orientation. Journal of management, 39(2), 339-365.

Huff, L., \& Kelley, L. (2003). Levels of organizational trust in individualist versus collectivist societies: A seven-nation study. Organization Science, 14(1), 81-90.

Jiang, Z. (2015). The relationship between justice and commitment: the moderation of trust. Asia-Pacific Journal of Business Administration, 7(1), 73-88.

Katou, A. A. (2013). Justice, trust and employee reactions: an empirical examination of the HRM system. Management Research Review, 36(7), 674-699. 
Kraft, J. M. (2008). Psychological contracts and organizational commitment profiles: Effects of contract fulfillment and violation on employee outcomes. Univerity of Windsor, Canada. Recuperado de http://www1. uwindsor. ca/people/ckwantes/system/files/Kraft\% 20MA\% 20Thesis. pdf.

Loi, R., Hang-Yue, N., \& Foley, S. (2006). Linking employees' justice perceptions to organizational commitment and intention to leave: The mediating role of perceived organizational support. Journal of Occupational and Organizational Psychology, 79(1), 101-120.

Möllering, G., Bachmann, R., \& Hee Lee, S. (2004). Introduction: Understanding organizational trust-foundations, constellations, and issues of operationalisation. Journal of Managerial Psychology, 19(6), 556-570.

Moore, T. (2014). The Impact of Psychological Contract Fulfillment on Employee Engagement in the Millennial Generation: The Moderating Effects of Generational Affiliation.

Newton, S. K., Blanton, J. E., \& Will, R. (2008). Innovative work and citizenship behaviors from information technology professionals: Effects of their psychological contract. Information Resources Management Journal, 21(4), 27.

Nisar, Q. A., Marwa, A., Ahmad, U., \& Ahmad, S. (2014). Impact of perceived organizational support on organizational citizenship behavior: Empirical evidence from Pakistan. International Journal of Research, 1(5), 231-240.

Robinson, S. L., Kraatz, M. S., \& Rousseau, D. M. (1994). Changing obligations and the psychological contract: A longitudinal study. Academy of management Journal, 37(1), 137-152.

Saleem, A., Nisar, Q., \& Imran, A. (2017). Organization citizenship behaviour, psychological empowerment and demographic characteristics: Teachers' perspective. International Journal of Advanced and Applied Sciences, 4(7), 129-135.

Singleton, R., Straits, B., \& Straits, M. (2005). Approaches to Social Sciences: New York: Oxford University Press.

Tan, H. H., \& Lim, A. K. (2009). Trust in coworkers and trust in organizations. The Journal of Psychology, 143(1), 45-66.

Tsai, W.-C., Chen, C.-C., \& Liu, H.-L. (2007). Test of a model linking employee positive moods and task performance. Journal of Applied Psychology, 92(6), 1570.

Wazir, M. S., Shaikh, B. T., \& Ahmed, A. (2013). National program for family planning and primary health care Pakistan: a SWOT analysis. Reproductive health, 10(1), 60.

Yang, J., Campobasso, N., Biju, M. P., Fisher, K., Pan, X.-Q., Cottom, J., . . Hong, X. (2011). Discovery and characterization of a cell-permeable, small-molecule c-Abl kinase activator that binds to the myristoyl binding site. Chemistry \& biology, 18(2), 177-186. 